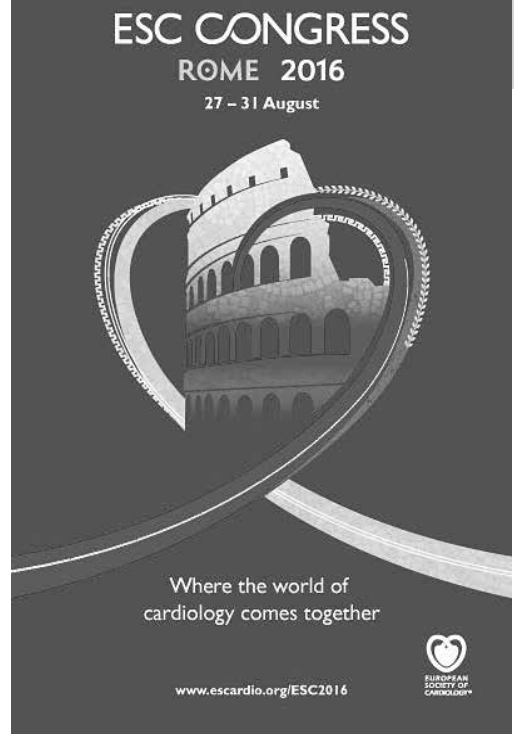

Jikn Vkpolith o Medicine of Ukreine

No7-8 (203-204) /2016

А.А. БАЗИАЕВИЧ, А. МеА. Н., професор; М.Я. КУАЕШІР, О.В. ГАИРЯ, К. меА. Н.; X.A. KAMIHCbKA

/^ьвівський національний меАичний університет імені Аанила Галицького/

\title{
Європейський конгрес кардіологів
}

Європейський конгрес кардіологів - найважливіша подія року для всіх кардіологів світу. Цього року конгрес, який по праву вважається одним із найбільш масштабних і значущих подій у світовій медицині, відбувся у величавому Римі в період 327 до 31 серпня 2016 року. Щорічно захід збирає практикуючих лікарів, вчених, працівників охорони здоров'я 3 країн Європи і всього світу. Українські фахівці також взяли участь у цьому найбільшому форумі: поділилися власними напрацюваннями та ознайомилися $з$ останніми досягненнями в кардіології.

Цього року конгрес знову побив власний рекорА віАвіАуваності - в його роботі взяли участь понаА 32 тисячі Аелегатів з більше ніж 140 країн світу. В наукових матеріалах конгресу опубліковано понаА 4500 тез. ОАночасно АОповіАі провоАилися в 27 аудиторіях. Тому кожен з учасників міг віАвіАати лекції з тематикою, що викликала в нього найбільше зацікавлення.

Основною метою конгресу була організація співпраці поміж консервативним карАіологом, інтервенційним карАіологом та кардіохірургом (формування “серцевої команди» - heart team). В такому випаАку кінцевим результатом має бути вибір оптимального лікувальної стратегії пацієнта з ішемічною хворобою серця.

Багато років основні завАання форуму залишаються незмінними: це обмін АОсвіАОМ у питаннях профілактики, Аіагностики та інноваційних методів Аікування захворювань серцево-суАинної системи, обговорення проблем і перспектив розвитку карАіологічної служби в різних країнах і регіонах, Аемонстрація сучасних Аосягнень меАицини. Цього року програма конгресу вк^ючала пленарні засіАання, симпозіуми, Аискусії, форуми, постерні сесії, виступи на виставкових майАанчиках, інтерактивні засіАання, круглі столи, гарячі лінії тощо. За Аопомогою сучасних засобів комунікації в Ані конгресу щоАня зАійснювалася безкоштовна електронна розсилка з основними новинами і прес-релізами Аля всіх зареєстрованих на офіційному сайті фахівців, онлайн-канал у режимі реального часу транслював наукові заходи конгресу.

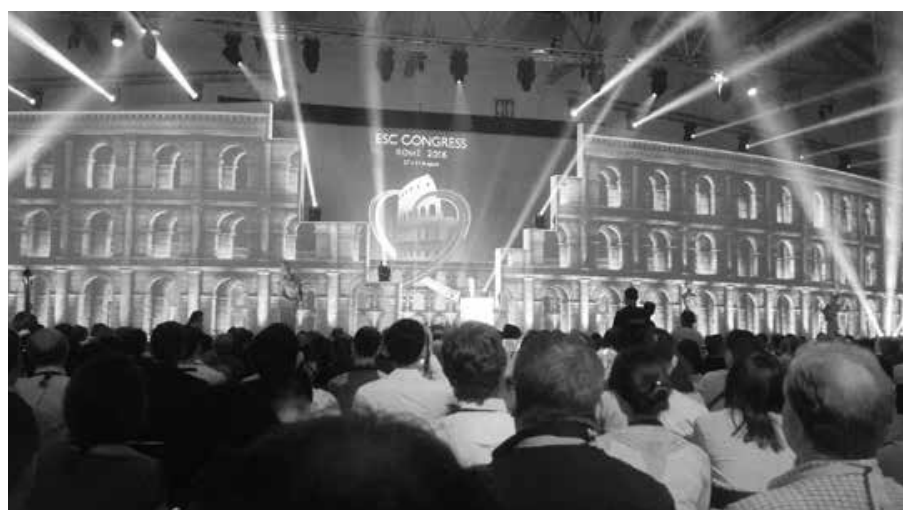

Традиційно піАвищений інтерес викликали сесії HotLine з поАанням і ОНАайН-обговоренням результатів великих наукових і клінічних АосліАжень. Протягом 5 Анів з різних напрямів - ішемічна хвороба серця (IXC), гострий інфаркт міокарАа (IM), аритмії, фібриляції передсераь (ФП), волії ритму, цукровий діабет (ЦА), фармакологія, артеріальна гіпертензія (АГ), серцева недостатність (CH), захворювання СуАин - було преАставлено результати безлічі кАінічних АОсліАжень, вик^аАено оновлені кАінічні рекоменАації, висвітлено провіАні метоАики Аіагностики та лікування в форматі живої АИскусії. В ціломУ вкрай ск^аАно виАілити головні теми минулого заходу. Спробуємо зупинитися на найбільш обговорю-

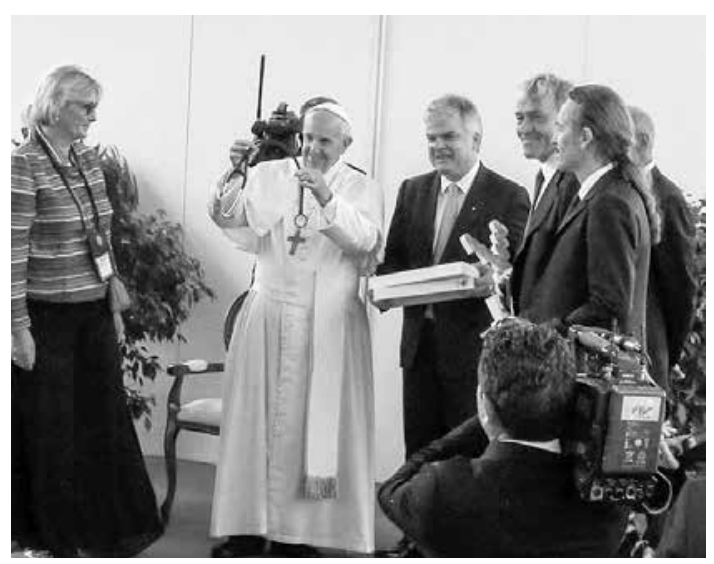

Папа Римський Франциск благословив учасників конгресу

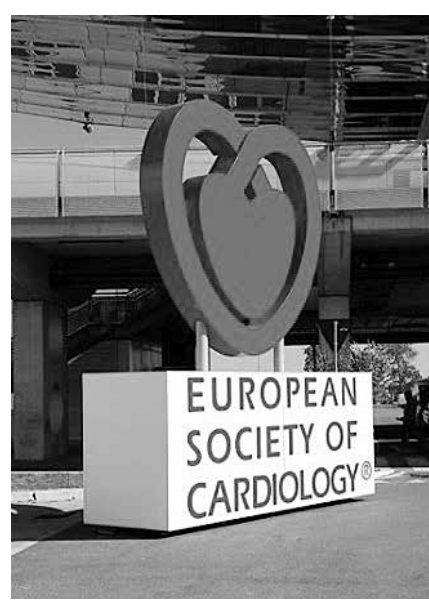

Президент Європейського товариства кардіологів, професор Фаусто Пінто та аспірант кафедри сімейної медицини ФПдО Львівського національного медичного університету імені Данила Галицького, лікар-кардіолог Григорій Кияк (фото Д. Беша) 
ваних, актуальних, резонансних поліях Європейського конгресу кардіологів - 2016.

На конгресі також було преАставлено оновлені рекоменАації з ведення пацієнтів з АисліпіАемією, гострою та хронічною серцевою недостатністю, фібриляцією передсерАь, а також з проФілактики серцево-суАинних захворювань у клінічній практиці. Крім цього, вперше було презентовано рекоменАації з лікування онкологічної патології та карАіотоксичності ліків.

Усі АОповіАі бУли на фаховомУ та ОАНОчасно АеГКОАОСтупноМу рівні. Після кожної з них віАбувалася Аискусія, в якій могли взяти участь всі охочі. В ній можна було як поставити запитання Ао ^ектора, так і висловити власну Аумку щодо преАмету Аискусії.

У спільному Аокументі Європейського товариства кардіологів та Європейського товариства з вивчення атеросклерозу піАнімається питання необхіАності зниження рівня ліпіАів крові як у загальній популяції, так і у пацієнтів високого ризику.

У пацієнтів з резистентною гіперхолестеринемією рекоменАовано призначення комбінованої терапії, що включає застосування статину та езетимібу. Також у всіх пацієнтів, незалежно віА ризику, необхіАно Аосягати як мінімум 50\% зниження рівня холестерину та холестерину ^іпопротеїАів низької густини (АПНГ). Цільове значення холестерину АПНГ у пацієнтів високого ризику становить менше 2,6 ммоль/^.

У рекоменАаціях порушуються питання застосування інгібіторів та PCSK9 - їх призначення може розгляАатися в разі збережен-

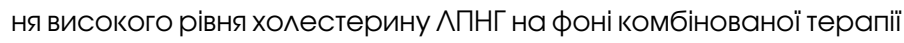
статинами та езетимібом. Як виявилося, вони можуть бути високоефективними і у пацієнтів з тяжкою сімейною гіперхолестеринемією. 3 іншого боку, висока вартість терапії може обмежувати ї застосування в Аеяких країнах.

Ще оАним нововведенням став той факт, що тепер при взятті аналізу крові на рівень холестерину пацієнт не обов' язково повинен бути натщесерце, оскільки результати провеАених АосліАжень виявили оАнаковий рівень ліпіАів при заборі крові натще і після прийому їжі.

На сьогоАнішній Аень антикоагулянтною терапією першої лінії $€$ нові пероральні антикоагулянти. ОАнак антагоністи вітаміну К, такі як варфарин, залишаються основними препаратами Аля профілактики інсульту при фібриляції передсередь і $\epsilon$ препаратами вибору у пацієнтів, яким не показані нові пер-

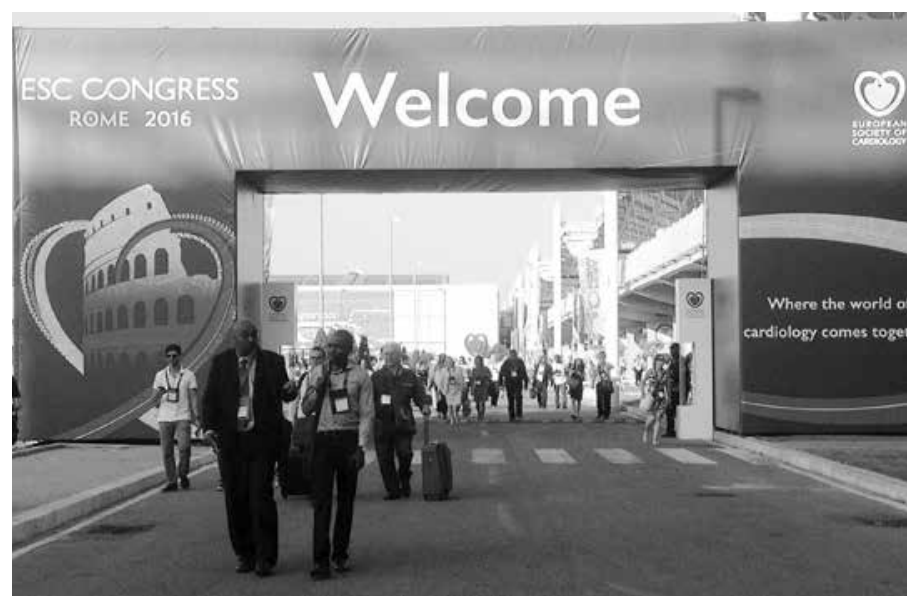

оральні антикоагулянти, зокрема за наявності механічних клапанів серця.

ОАна з кАючових змін у нових рекоменАаціях торкнулася вирішення питання про ініціювання антикоагулянтної терапії. Так, антикоагулянтну терапію сліА призначати за наявності 1 балу за шкалою CHA2DS2-VASc у чоловіків і 2 балів - у жінок.

У певної групи пацієнтів з терапією першої лінії рекоменАовано проведення катетерної абляції. При цьому кращим є ізоляція гирла ^егеневих вен, а більш розширені втручання рекоменАовані як терапія резерву у пацієнтів з рециАивуючою ФП.

У нових рекоменАаціях з карАіо-онкології розгляАаються серцево-суАинні усклаАнення протиракової терапії.

Увага сфокусовано на 9 категоріях: Аисфункція міокарда та CH; IXC; к^апанна хвороба; аритмії; артеріальна гіпертензія; тромбоемболічні стани; захворювання периферичних артерій та інсульт; легенева гіпертензія; усклалнення з боку перикарАа.

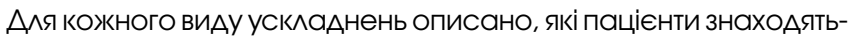
ся в групі ризику, як визначити і запобігти розвитку можливих побічних ефектів терапії, які принципи лікування та спостереження за пацієнтами обрати.

Наприк^аА, спільне застосування антрациклінів і трастузумабу у пацієнток з раком молочної залози значно піАвищує ризик розвитку СН. ОАНаК КарАіОтоксичність МОжна значимо зменшити шляхом провеАення терапії з інтервалами без комбінованого призначення препаратів.

Було преАставлено ОНовлені рекоменАації щоАО застосування нових пероральних антикоагулянтів у пацієнтів з ФП. Нижче наведено 9 кАючових позицій із застосування нових пероральних антикоагулянтів при неклапанній фібриляції переАсерАь.

1. РекоменАації містять в собі таблицю з віАОмими на сьогоАнішній Аень взаємоАіями між препаратами, які можуть вплинути на Аозування нових пероральних антикоагулянтів. Важливі взаємоАії включають АронаАерон (з Аабігатраном), рифампіцин, інгібітори протеаз, що застосовуються при ВІА, протигрибкові препарати (інтраконазол і кетоконазол), циклоспорин і такролімус (з Аабігатраном), карбамаземін, фенобарбітал, фенітоїн.

2. У рекоменАаціях описується стратегія переходу між прийомом варфарину і новими пероральними антикоагулянтами. Зазвичай при переході з прийому варфарину на новий пер-

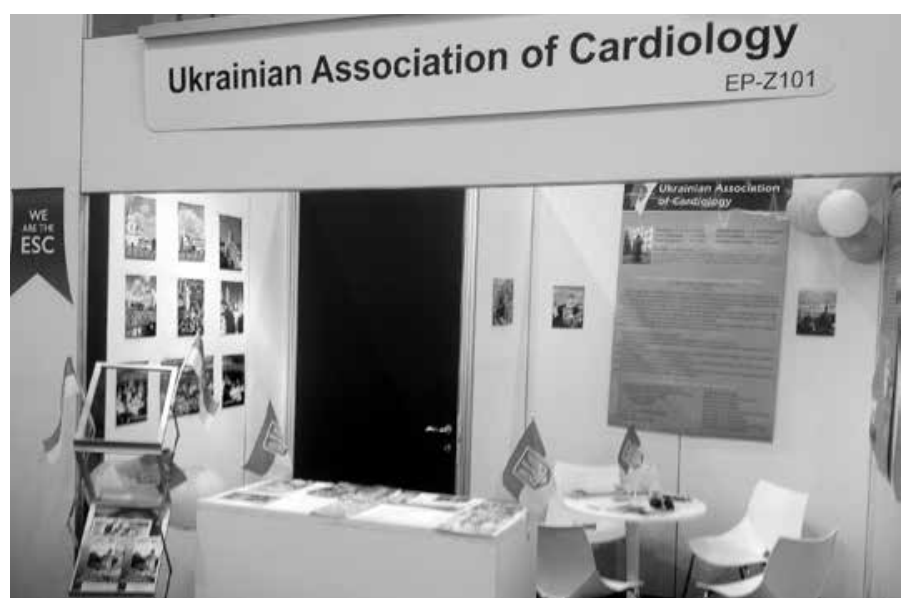


оральний антикоагулянт останній призначають після того, як МНО становить $\leq 2,0-2,5$. При перехоАі з нового перорального антикоагулянта на варфарин сліА оцінити рівень МНО переА призначенням препарату та через 24 години після його останнього прийому. При цьому в перший місяць прийому варфарину реКОменАУється ЖорстКИй КОНтроль МНО.

3. Щодо періпроцеАурної антикоагуляції застосування НМГ 3 метою «bridge»-терапії не рекоменаується. Час призначення останньої Аози нового перорального антикоагулянта переА процеАурою залежить віА стану функції нирок пацієнта і ризику кровотечі, пов' язаного з втручанням. Зазвичай прийом нових пероральних антикоагулянтів сліА припинити за 24-96 гоАин АО операції.

4. У пацієнтів з кровотечею, асоційованою з прийомом нових пероральних антикоагулянтів, в більшості випаАків Аостатньо консервативної стратегії ведення. При виникненні масивної або загрозливої Аля життя кровотечі у пацієнтів, які приймають Аабігатран, обґрунтованим є призначення 5 мг іАаруцизумабу внутрішньовенно. При прийомі інгібіторів Ха-фактора, поки аАнексанет-альфа не буАе схвалений і Аоступний, призначають концентрат протромбінового комплексу в Аозі 50 ОА/Кг.

5. У пацієнтів, яким зап^анована карАіоверсія, Аосить 3-тижневого прийому нового перорального антикоагулянта АО процеАури, при цьому проведення черезстравохіАної ехокарАіографії не потрібне. У пацієнтів з тривалістю пароксизму ФП Ао 48 гоАин рекоменаується преконверсійне застосування НМГ і прийом нових пероральних антикоагулянтів протягом мінімум 4 місяців після віАНОв^ення синусового ритму.

6. Пацієнтам, які приймають новий пероральний антикоагулянт, яким належить провеАення п^анового черезшкірного коронарного втручання (ЧКВ), рекоменАується віАміна прийому препарату мінімум за 24 години переА провеАенням процеАури. При наАхоАженні пацієнта з гострим Коронарним синАромом (ГКС) прийом перорального антикоагулянта скасовується. Після проведення ЧКВ і/або скасування парентеральної антикоагуляції прийом нового перорального антикоаГУАЯнта поновАюєтьСя в тій самій АОзі, що й переА поАієЮ, в комбінації з оАним або Авома антитромбо-

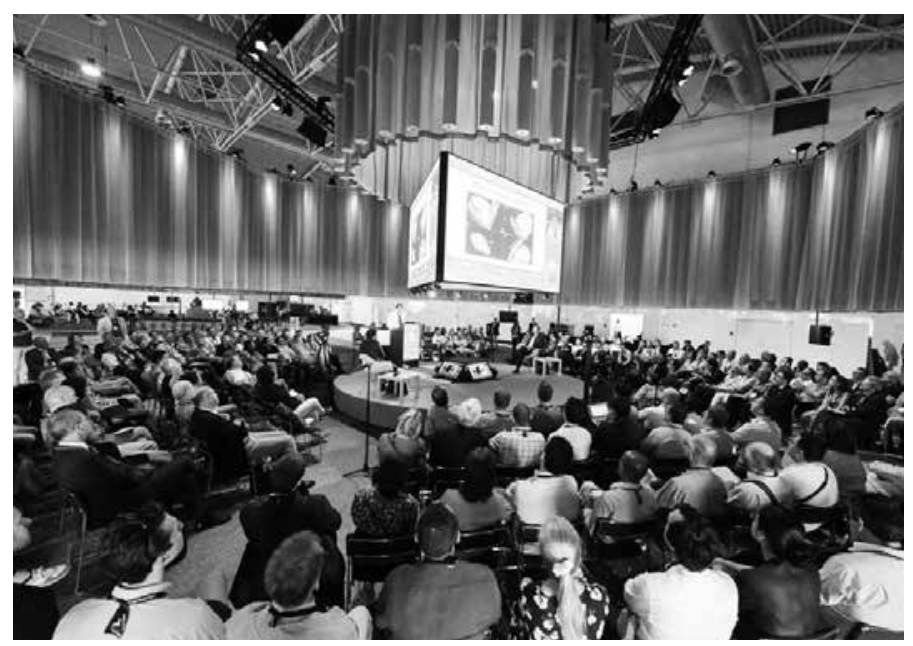

цитарними препаратами. У Ааній категорії пацієнтів сліА розгляАати призначення інгібіторів протонної помпи.

7. Після п^анового ЧКВ або ГКС пацієнтам з ФП рекоменАується прийом потрійної терапії тривалістю 1 або 6 місяців при установці простих таелютинг-стентів віАповіАно. НаАалі рекоменАовано прийом антикоагулянта і аспірину або к^опіАогрелю терміном Ао 1 року. Більшість пацієнтів через рік після поАії можуть приймати ^ише антикоагулянт.

8. Пацієнтам, які перенесли транзиторну ішемічну атаку або ішемічний інсульт, рекоменАована ініціація або віАновлення терапії новими пероральними антикоагулянтами через 1-12 Анів піс^я поАії залежно віА тяжкості останнього. У пацієнтів із внутрішньочерепним крововиливом в разі можливості усунення причини або факторів ризику кровотечі віАНовлення терапії рекоменАовано через 4-8 тижнів; в іншому випаАку сліА РОзгАяАати можАивість провеАення ОКАюзії вушка лівого переасерая.

9. Ао призначення нових пероральних антикоагулянтів всім пацієнтам сліА оцінювати ниркову функцію із застосуванням формули Кокрофта-Голта. Терапія Ааними препаратами не показана пацієнтам з тяжкою нирковою недостатністю (кліренс креатиніну менше 15 м^/хв або системний гемодіаліз). Моніторинг ниркової функції має проводиться з інтервалом, розрахованим за формулою: кліренс креатиніну / 10 (місяців).

ЗгіАно з результатами нового АОсліАження у осіб віА 65 років і старше за умови систематичного помірного фізичного навантаження знижується ризик Серцево-суАинної смерті та гострого коронарНого СИнАрОму. АОсліАНИКИ Оцінювали зв'язОК міЖ фізичною активністю і ризиком серцево-суАинних захворювань та смерті шляхом аналізу Ааних опитуваних, а також результатів кАінічних обстежень, які включають рівень артеріального тиску, ріст, масу тіла і ^абораторних Ааних, в тому числі рівень холестерину.

Автори класифікували низьку фізичну активність як читання, перегляА телевізора і роботу по Аому; помірну - піші прогулянки, їза на велосипеАі або легкі фізичні вправи; високу - спортивні ігри або інтенсивні фізичні тренування. Було виявлено, що помірні фізичні навантаження знижують ризик розвитку гострої серцевоСуАинного поАії на 30\%, а серцево-суАинної смерті-на 50\%. Більш
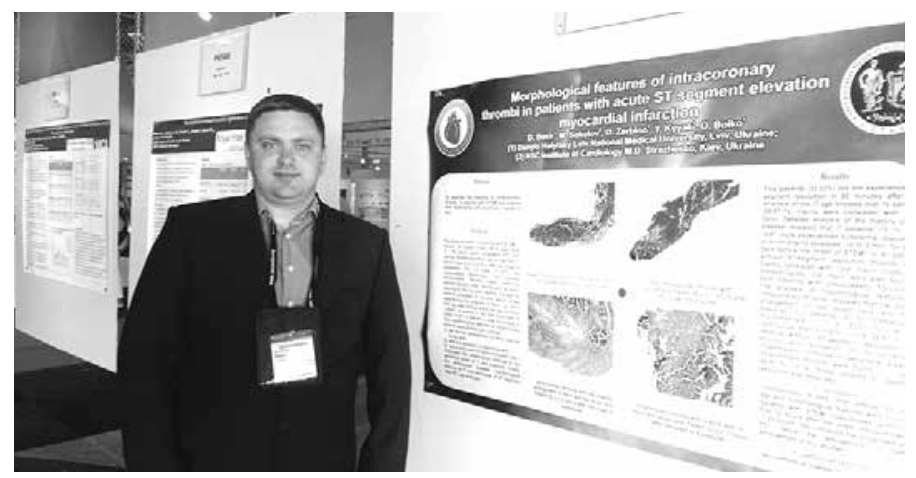

На конгресі асистент кафедри сімейної медицини ФПдО Львівського національного медичного університету імені Данила Галицького, кандидат медичних наук Дмитро Беш представив постер на тему «Морфологічні особливості інтракоронарних тромбів у пацієнтів з гострим інфарктом міокарда з підйомом сегмента ST» (фотоГ. Кияка) 
високий рівень фізичних навантажень призводить Ао ще більшого зниження зазначених ризиків.

АосліАження EROSION показало, що упонаА 25\% пацієнтів з ГКС, при якому зазвичай провоАиться ЧКВ зі стентуванням, можна не проводити Аану процеАуру, а обмежитися лише призначенням антитромботичної терапії.

В Ааному АОсліАженні 405 паціентів з ГКС, які поступали АО віААі^ення невіАК^аАНої АОпомоги та яКих направ^я^и на ангіограФію коронарних суАин, паралельно провоАили оптичну когерентну томографію (ОКТ) з метою Аиференціації ерозії та розриву атеросклеротичної бляшки. Ааним пацієнтам була призначена антитромботична терапія без провеАення стентування - аспірин і тікагрелор. Аолатково 63,6\% Ааних пацієнтів отримували блокатор глікопротеїнових Ilb/llla-рецепторів.

Через 1 місяць періоду спостереження 47 із 60 (78,3\%) пацієнтів Аосягли кінцевої точки - більше ніж 50\% зменшення розміру тромбу. У 22 пацієнтів тромб не візуалізувався взагалі.

За словами авторів, це АосліАження вперше пролемонструвало, що у пацієнтів з ГКС, викликаним ерозією атеросклеротичної бляшки, може мати перевагу неінвазивна стратегія із застосуванням антитромботичних препаратів.

За результатами нового АосліАження YEARS розроблено новий алгоритм, якКЙ АОзволяє просто і точно вИКАючити наявність у пацієнта тромбоемболії легеневої артерії (TE^А) без провеАення КТ-ангіографії легеневих суАин.

На віАміну віА інших алгоритмів Аіагностики, YEARS ск^аАवється з аналізу оАноразового вимірювання D-Аимеру, оцінки наявності кАінічних Ознак тромбозу глибоких вен (наприклаА, набряку гомілок), кровохаркання, а також оцінки Аікаря щоАо того, що TE^А $€$ найбільш вірогіАною патологією.

Авториперспективно оцінили застосування алгоритму у 3465 пацієнтів (сереАній вік - 53 роки), 88\% яाких обстежувалися на амбулаторному етапі. На піАставі алгоритму ТЕАА була викАючена, а провеАення КТ-ангіографії-скасовано у 1651 паціента, у яких або не було ознак за алгоритмом і рівень D-Аимеру був нижче 1000 нг/м^, або була одна або більше ознак, а рівень D-Аимеру становив менше 500 нг/м^. Всі інші пацієнти були направлені на проведення КТ-ангіографії.

Пацієнтам, у ялких ТЕАА була виключена, Аікування не провоАилося 3 поАальшим періоАом спостереження протягом 3 місяців. Пацієнти з Аіагностованою ТЕАА отримували антикоагулянти. За словами авторів, перевагаYЕARS наА наявними алгоритмами полягає в тому, що його застосування АОзволяє на 14\% знизити необхіАність проведення КТ-ангіографії, що зменшує ризик потенційної шкоАи, пов' язаної з випромінюванням, а також ймовірність гіперАіагностики.

За результатами АосліАження DANISH профілактична імплантація карАіовертера-Аефібрилятора (IKA) у пацієнтів з симптомною систолічною серцевою неАОстатністю, не викликаною IXС, і фракцією викиАу (ФВ) $\leq 35 \%$ не зумовлює Аостовірне зниження Аовгострокового ризику смерті віА усіх причин порівняно зі станАартним Аікуванням.

Автори вкАючили в АОсліАження 1116 пацієнтів, 556 з яких було імплантовано IKA, а 560 пацієнтам призначена меАикаментозна терапія. В обох групах 58\% пацієнтів був імп^антований пристрій А^я ресинхронізаційної терапії. За результатами виявилося, що через 5,6 року періоду спостереження первинної кінцевої точки- смерті віА всіх причин - Аосягли 120 пацієнтів групи IKА порівняно з 131 пацієнтом групи станАартної терапії. За словами авторів, було віАзначено важливий зв' язок результатів за віком, який свіАчить про те, що у більш молоАИх пацієнтів віАзначається користь віА імп^антації IКА. Так, в піАгрупі пацієнтів молоАше 59 років імп^антація ІКА асоціювалася зі зниженням ризику смерті віА усіх причин на 49\%.

За результатами АОсліАження NACIAM виявилося, що внутрішньовенне ввеАення N-वцетилцистеїну в комбінації з нітрогліцерином Аостовірно зменшує приблизно на третину розміри зони ураження міокарАа у пацієнтів із ГІМ з елевацією сегмента ST, яким проВОАИ^ОСЯ ЧКВВ.

У АосліАження було включено 112 пацієнтів з ГІМ з елевацією сегмента ST (сереАній вік - 64 роки), які наАійшли в оАну із трьох кАінік Австралії протягом 12 гоАин віА початку симптомів. Всім пацієнтам була призначена інфузія нітрогліцерину і висока Аоза N-ацетилцистеїну (15 г на Аобу) або плацебо. АосліАжуваним через 1 тижАень і через 3 місяці після поступлення провоАили МРТ серця. Виявилося, що в групі пацієнтів, які отримували N-ацетилцистеїн, порівняно з групою плацебо віАзначався на 33\% і 50\% віАповіАно менший розмір інфаркту. Також була віАзначена схожа, але не Аостовірна тенденція Ао зменшення рівня креатинфосфокінази.

Максимальна ефективність віАзначалася у пацієнтів, яким комбінована терапія проводилася в ранній періоА - протягом 3 гоАин віА Моменту виникнення Симптомів. Через 2 роки періоАу спостереження комбінованої точки - повторна госпіталізація з кардіальних причин або смерть - Аосягли 3 пацієнта групи $\mathrm{N}$-ацетилцистеїну та 16 пацієнтів групи п^ацебо.

Кінцеві точки безпеки - гіпотензія, кровотеча, контраст-інаукована нефропатія - між групами не віАрізнялися.

ПроАовження інфузії біваліруАином протягом кількох гоАин після завершення черезшкірного коронарного втручання не призводить АО виникнення ішемічних проблем та кровотечі. Порівняння про^онгованого ввеАення порівняно з припиненням піс^я інфузії ЧКВ було останнім із завАань, що стояли в АОсліАженні MATRIX. Ава інші Стосувалися порівняння раАіального і феморальноГО піАХОАів при ЧКВ (були виявлені Аостовірні переваги раАіального піАхоАу), а також антитромботичного препарату вибору гепарину або біваліруАину (обиАва препарати прОАемОНСтрУвали ОАНаКОвиЙ вплив на АОсягнення первинної кінцевої точки).

Конгрес карАіологів - 2016 запам' ятається учасникам не лише розмахом захоАу і технічними нововвеАеннями, а й преАставленими АОСАіАЖеНнями, які охоплюЮть Різноманітні напрями карАіо^огії - віА безпосереАніх метоАів Аікування і Аіагностики, сучасних оперативних метоАик і презентацій нових рекоменАацій Ао цікавих в практичному плані Аискусій, оригінальних робіт і нестанАартних піАХОАіВ АО вирішення РУтинних питань.

Закриття конференції віАвіАав Папа Римський Франциск. У своїй промові він наголосив на значній ролі карАіологів у поАОвженні тривалості та піАвищенні якості життя пацієнтів, а також благословив усіх учасників конгресу.

Наступний форум карАіологів віАбудеться 26-30 серпня 2017 року у Барселоні (Іспанія).

Фото надані А. Бешом та Г. Кияком. Також використані фото з сайту: https://www.facebook.com/europeansocietyofcardiology/ photos/ 